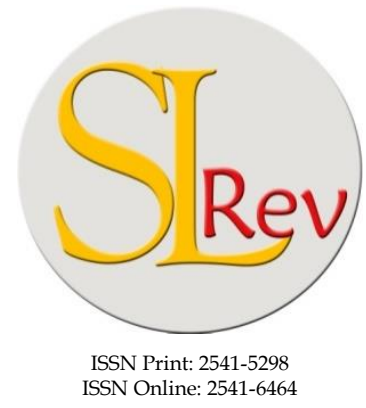

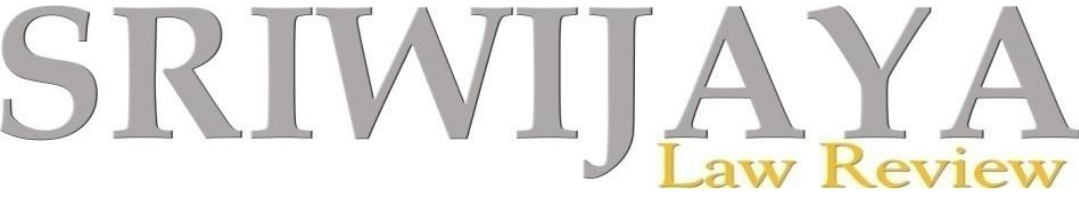

Editorial Office: Faculty of Law, Sriwijaya University, Jalan Srijaya Negara, Palembang, South Sumatra 30139, Indonesia. Phone: +62711-580063Fax: +62711-581179

E-mail: sriwijayalawreview@unsri.ac.id| sriwijayalawreview@gmail.com Website: http://journal.fh.unsri.ac.id/index.php/sriwijayalawreview

\title{
Applying the Advocacy Coalition Framework to Understand the Process of Local Legislation in Indonesia
}

\author{
Alamsyah*, Sri Suwitri**, Kismartini**, and Yuwanto**
}

\begin{abstract}
Making regulation is the primary function of the modern state. Current praxis shows how there is positive and negative cooperation among policy participant in the process of local legislation. Many Indonesian scholars give attention to the politics of law and citizens participation in understanding this process. However, they do not give detail analysis on cooperation among policy participant during the legislation process. Drawing on qualitative methods, this article applies the Advocacy Coalition Framework (ACF) to understand the process of local legislation in South Sumatra Province. This article selects The Provincial Regulation of South Sumatera No. 8 of 2016 on the Forest Fires Mitigation as a case study due to the nature of forest fires as the public problem that obtains attention from various actors. Several key informants representing the executive and the legislative at the local level is selected using the purposive technique as a source of primary data. The secondary data is collected from the official publication of the policy participant, newspaper, and social media. Using interactive models and NVIVO software to code and analyse research data, this article finds that the secondary policy belief (SPB) among policy participant could be similar partially or wholly. This similarity is the foundation of policy participant to make an advocacy coalition. This article identifies two advocacy coalition in legislation process of The Provincial Regulation of South Sumatera No. 8 of 2016 on the Forest Fires Mitigation: 'the local wisdom' coalition vs. 'the no burning policy' coalition. This article discusses the findings and propose a new agenda for further research on local legislation process.
\end{abstract}

Keywords: Advocacy Coalition; Forest Fires; Local Legislation; Policy Beliefs; Policy Formulation.

\section{ARTICLE HISTORY:}

\section{DOI: 10.28946/sIrev.Vol3.Iss1.136.pp34-47}

Received: Jul 01, 2018;

Reviewed: Nov 01, 2018;

Accepted: Jan 10, 2019;

Published: Jan 31, 2019.

Faculty of Social and Political Science, Sriwijaya University, Email: alamsyah78@fisip.unsri.ac.id

** Faculty of Social and Political Science, Diponegoro University, Email: sri_suwitri@yahoo.co.id/kis_martini@yahoo.co.i d/yuwantosaja@yahoo.com

\section{INTRODUCTION}

In 2016, Ministry of Home Affairs rejects 3.143 local regulation produced by local government (province government and district government). ${ }^{1}$ It indicates closed and positive cooperation between the executive,

Ihsanuddin. (2016) Daftar 3.143 Perda Yang Dibatalkan Sudah Bisa Diunduh Di Situs Kemendagri. Kompas. [Online]. Available at: http s://nasional.kompas.com/read/2016/06/21/152004 01/daftar.3.143.perda.yang.dibatalkan.sudah.bisa. diunduh.di.situs.kemendagri (retrieved: June 09, 2017). 
bureaucracy, and the legislative at the local level. In the same time, as reported by Ministry of Home Affairs, 313 local head were arrested as bribery suspects during 2004 - 2017 periods in several sectors such as local budgeting, local tax, public procurement, social grant, official travel, and licensing. Private sector and the local legislature are also participating in this practice. In this case, there is contrary cooperation between the executive, the bureaucracy, the legislature, and the private sector. The question is how to understand the "cooperation" between the policy participant during the formulation of the local legislation?

Theoretically, regulation is one of the attributes of a modern state. It has functions, for example, to redistribute income and wealth, ${ }^{2}$ reducing monopoly of power and the elimination of specific forms of price discrimination, ${ }^{3}$ and correcting market failure. ${ }^{4}$ The scholars have different perspectives in understanding "the cooperation" between the players in the formulation of regulation. The economic theory of regulation, for example, assuming that the primary function of regulation is transferring

Sam Peltzman. (1976) Toward a More General Theory of Regulation. The Journal of Law and Economics. [Online] 19 (2), 211-240. Available at: doi:10.1086/466865; W.T. Stanbury and George Lermer. (1983) Regulation and the Redistribution of Income and Wealth. Canadian Public Administration/Administration Publique Du Canada. [Online] 26 (3), 378-401. Available at: doi:10.1111/j.1754-7121.1983.tb01033.x.

3 George J Stigler and Claire Friedland. (1962) What Can Regulators Regulate? The Case of Electricity. The Journal of Law and Economics. [Online] 5, 1-16. Available at: doi:10.1086/466579.

4 Andrei Shleifer. (2005) Understanding Regulation. European Financial Management 11. [Online] 4, 439-451. Available at: doi:10.1111/j.1354-7798.2005.00291.x. wealth through a political market. This market has been influenced by the demand side (the constituents) and the supply side (the political representatives). ${ }^{5}$ For the economic theory of regulation, cooperation among actors in the legislative process is the effect of supply-demand interaction.

The second point of view is the public choice theory, a variant of the economic theory of regulation. In the simple form, as suggested by Tollison ${ }^{6}$, legislation process could be formulated as follows: $\mathrm{L}=\mathrm{f}$ (POP, INC, ASSOC, SIZE, RATIO, MAJ), where $\mathrm{L}=$ legislation process; $\mathrm{POP}=$ population; $\mathrm{INC}=$ real income; ASSOC $=$ the number of trade association; SIZE = legislative size; RATIO $=$ the ratio of the size of the House to the size of the Senate; and MAJ = the size of legislative majority. The public choice theory is also concerned on the effect of political player (i.e., politicians, bureaucrat, interest group, private corporation, mass media, and so on) behaviour on the legislative process. They introduced several important concepts to understanding legislation process such us rent-seeking behaviour, climber bureaucrat, bureaucratic politics, and budget maximiser, ${ }^{7}$ optimum destructive regulation. ${ }^{8}$ For public choice theory, cooperation between actors in the legislative process is the product of bar-gaining among

Peltzman, "Toward a More General Theory of Regulation," pp211-240.

6 Robert D Tollison, 1988, "Public Choice and Legislation," Virginia Law Review, 74 (2), pp339-371.

7 John A C Conybeare. (1982) Politics and Regulation: The Public Choice Approach. Australian. Journal of Public Administration. [Online] 41 (1), 33-45. Available at: doi:10.1111/j.1467-8500.1982.tb00571.x.

8 Richard B. McKenzie and Hugh H Macaulay. (1980) A Bureaucratic Theory of Regulation. Public Choice. [Online] 35 (3) 297-313. Available at: doi:10.1007/BF00124443. 
rational actors who attempt to maximizing self-interest.

The third perspective is agency theory who see legislation process as the principalagent relationship. For agency theory, regulation is an instrument for the regulators (principal) to control or influence the activity or the available choice of the regulated (agent). Both the principal and the agent have constraints and problems in this relationship. The agent face problems to recognize the principal preferences, acquire knowledge of what acts will be compatible with those preferences, obtain knowledge of how to perform those acts. The principal has problems in transmitting their preferences to agents, educating agents or indicating what acts would service those preferences, monitoring the agent's performance, and preventing and correcting any deviation by the agent from desired performance levels. ${ }^{9}$ For agency theory, cooperation between the players in legislation process is the problem of principal-agency relationship.

The sixth is discourse analysis approach which defines regulations as "a process involving the sustained and focused attempt to alter the behaviour of others according to identified purposes with the intention of producing a broadly identified outcome or outcomes which may involve mechanisms of standard-setting, information-gathering, and behaviour modification." For this approach, the legislation process is "the communicative interactions that occur between all involved in the regulatory 'space' (regulatory process)." It is also contestation for the meaning and the relationships of

9 Barry M. Mitnick. (1982) Regulation and the Theory of Agency. Review of Policy Research. [Online] 1 (3) 442-453. Available at: doi:10.1111/j.1541-1338.1982.tb00448.x. language, identities, thought, knowledge, and power. ${ }^{10}$ For this approach, cooperation among actors in the legislation process is the struggle of power through meaning, identities, thought, and knowledge. However, all the theories on the above do not explain the influence of the belief system to cooperation between actors in the legislation process. In the same time, many Indonesian scholars are also ignoring the belief system in their empirical research on the legislation process. To the best of our knowledge, Indonesian scholars only give attention to the influence of the politics of law from the executive of the legislative to legislation process ${ }^{11}$ and citizens participation in legislation process, ${ }^{12}$ especially women, ${ }^{13}$ Islamic organization, ${ }^{14}$ and private sector. ${ }^{15}$ As will explained later,

10 Julia Black. 2002. Regulatory Conversations. Journal of Law and Society. [Online] 29 (1) 163196. Available at: doi:10.2307/4489085.

11 Ruslan Abdul Rasyid, 2013, "Politik Hukum Pembentukan Peraturan Daerah Nomor 5 Tahun 2006 Tentang Investasi Infrastruktur Jalan Dan Landing Site Eks Jalan Pertamina Oleh Pemerintah Kabupaten Barito Timur," Arena Hukum, 6 (3), pp290-307.

12 Amir Muhiddin, 2013, "Partisipasi Masyarakat Dalam Pembuatan Peraturan Daerah (Perda)," OTORITAS: Jurnal Ilmu Pemerintahan, 3 (1), pp1-9; Yusdiyanto Yusdiyanto. (2012) Partisipasi Masyarakat Dalam Pembentukan Program Legislasi Daerah," Fiat Justisia. [Online] 5 (2). Available at: doi:10.25041/fiatjustisia.v5no2.66; Ahmad Saleh. (2015) Peran Serta Masyarakat Di DPRD Dalam Pembentukan Peraturan Daerah. Fiat Justisia. [Online] 7 (2) 223-230. Available at: doi:10.25041/fiatjustisia.v7no2.381.

13 Riris Ardhanariswari, Sofa Marwah, and Tedi Sudrajat. (2008) Keterlibatan Perempuan Dalam Penyusunan Produk Hukum Di Kabupaten Banyumas. Jurnal Dinamika Hukum 8 (1) 56-63. Available at: doi:10.20884/1.jdh.2008.8.1.33.

14 Imam Sucahyo, 2017, "Partisipasi Stakeholders Islam Dalam Upaya Mereformasi Peraturan Daerah Tentang Usaha Tempat Hibutan Di Kota Probolinggo," Publisia, 2 (2) (2017), pp130-145.

15 Sri Nurhidayati, (2013), "Proses Perumusan Kebijakan Pertambangan Di Kabupaten Sumbawa." JKAP (Jurnal Kebijakan Dan 
the Advo-cacy Coalition Framework (ACF) will contribute to filling this gap.

Historically, ACF was born as an alternative approach to understanding public policymaking which is dominated by the cyclical approach that stressing a sequential process (i.e., agenda-setting, formulation, implementation, and evaluation). ${ }^{16} \mathrm{ACF}$ begins from the argument that the most useful aggregate unit of analysis for understanding public policy process in modern industrial societies is not any specific governmental organization but rather a policy subsystem, i.e., those actors from a variety of public and private organizations who are actively concerned with a policy problem. ${ }^{17}$ Each actor has a set of hierarchical policy preferences or the belief system: deep core belief (DCB), policy core belief (PCB), and secondary policy belief (SPB).

DCB involves very general normative and ontological assumptions about human nature, the relative priority of fundamental values, the relative priority of the welfare of different groups, the proper role of government vs. markets in general, and about who should participate in governmental decision-making. DCB is largely the product of childhood social-

Administrasi Publik) 17 (1) 58-71. Available at: doi:10.22146/jkap.6849.

16 Keith Dowding. (1995) Model or Metaphor? A Critical Review of the Policy Network Approach. Political Studies 43 (1) 136-158. Available at: doi:10.1111/j.1467-9248.1995.tb01705.x;

Michael Hill and Peter Hupe, Implementing Public Policy, London, UK: SAGE Publication Ltd, 2002; Kevin B. Smith and Christopher W. Larimer, The Public Policy Theory Primer Colorado, U.S.A: Westvew Press, 2009.

17 Paul A Sabatier. (1986) Top-Down and BottomUp Approaches to Implementation Research: A Critical Analysis and Suggested Synthesis. Journal of Public Policy 6 (1) 21-48. Available at: doi:10.1017/S0143814X00003846. ization and, thus, very difficult to change. The next element of belief system is PCB which consists of the priority of different policy-related values, the relative authority of government and markets, the proper roles of policy participants, the relative seriousness and causes of policy problems. Because PCB is subsystem-wide in scope and deals with fundamental policy choices, they are also very difficult to change. The final layer of the belief system consists of SPB. SPB is relatively narrow in scope, for example, detailed rules and budgetary applications within a specific program, the seriousness and causes of problems in a specific locale, and public participation guidelines within a specific statute. Because SPB is narrower in scope than PCB, changing them requires less evidence and fewer agreements among subsystem actors and thus should be less difficult. ${ }^{18}$

All policy participants, based on the similarity of their PCB to another actor, make or join an advocacy coalition. ACF used 'advocacy coalition' terminology to explain a set of an actor from multiple levels of government who cooperate each other in a long period based on the non-trivial manner to influence public policymaking process. ${ }^{19}$ Each advocacy coalition has resources such as formal legal authority to make decisions, public opinion, information, mobilizable troops, financial resources, and

18 Paul A Sabatier and Christopher M Weible, The Advocacy Coalition Framework: Innovations and Clarifications, ed. Paul A Sabatier, Theories of the Policy Process, Colorado, U.S.A: Westvew Press, 1999.

19 H. C. Jenkins-Smith et al., "The Advocacy Coalition Framework: Foundation, Evolution, and Ongoing Research" in Theories of the Policy Process., ed. Paul A. Sabatier and Christopher M. Weible, Third, Colorado, U.S.A: Westvew Press, 2014, pp183-224. 
skilful leadership. ${ }^{20}$ At any point in time, each advocacy coalition adopts one or more strategies involving the use of 'guidance instruments' (changes in rules, budgets, personnel, or information) as a means of altering the behaviour of various governmental institutions to realize its policy objectives. Conflicting strategies from various advocacy coalitions are normally mediated by a third group of actors, here termed 'policy brokers', whose principal concern is to find some reasonable compromise that will reduce intense conflict. ${ }^{21}$

This research chooses The Provincial Regulation of South Sumatera No. 8 of 2016 on the Forest Fires Mitigation as the case study. Forest fires in Indonesia are a repetitive disaster and have received attention from various actors at the different level of government. Because forest fires are a public problem and hot issue, the author assumed that formulating The Provincial Regulation of South Sumatera No. 8 of 2016 on the Forest Fires Mitigation will also receive attention from various policy participant. It gives an opportunity for the researchers to examine the belief system and advocacy coalition of policy participant during the legislation process.

\section{RESEARCH METHODS}

This research is ex-post and a qualitative research. The ex-post mean that this research observed legislation process after The Provincial Regulation of South Sumatera No. 8 of 2016 on the Forest Fires

20 Sabatier and Weible, The Advocacy Coalition Framework: Innovations and Clarifications.

21 Paul A Sabatier. (1998) The Advocacy Coalition Framework: Revisions and Relevance for Europe. Journal of European Public Policy. [Online] 5 (1), 98-130. Available at: doi:10.1080/13501768880000051.
Mitigation has been enactment by the Governor of South Sumatera and the Regional of Legislative Council of South Sumatera Province. This attribute does not give an opportunity for the researchers to apply direct observation or participate at all stage of the legislative process in formulating a new local regulation. The qualitative mean that the overall research process would be based on a natural setting where the relationship between the researcher and participants are not mutually exclusive relationships, and that contextual constraints all help to shape inquiry. ${ }^{22}$ The primary data is collected through depth interview with several key informants such as the legislative committee, government agency, non-govern-mental organization, scientist, the mass media, and plantation corporation. Secondary data was gathered from the official publication of policy participant (i.e., archive meeting, report, website) and social media (i.e., Twitter and Facebook). This research uses interactive model $^{23}$ and NVIVO $11^{24}$ for analysing research data and the triangulation technique to cross-check data validation.

\section{ANALYSIS AND DISCUSSION The Setting}

Geographically, South Sumatera Province (SSP) located at $1^{\circ}-4^{\circ}$ South Latitude and $102^{\circ}-106^{\circ}$ East Longitude with a land area

22 Karyn Cooper and Robert E White, Qualitative Research in the Post-Modern Era: Contexts of Qualitative Research, Dordrecht, The Netherlands: Springer Science + Business Media B.V, 2012.

23 Matthew B Miles, A Michael Huberman, and Jhonny Saldana, Qualitative Data Analysis: A Method Sourcebooks, London, UK: SAGE Publication, 2014.

${ }^{24}$ QSR International Pty Ltd, NVIVO Qualitative Data Analysis Software, Melbourne, Australia: QSR International Pty Ltd, 2017. 
of $87,421.17 \mathrm{~km} 2$. It has a topography that varies from the coastal area, lowland, Highland, and mountains. The forest fires concentrated in the lowland area in the Eastern of SSP. It has a tropical and wet climate with varying rainfall per day $(61,0$ / 17 - 634,4 / $22 \mathrm{~mm}$ ) throughout the year. It also has temperatures between $26.4{ }^{\circ} \mathrm{C}$ to $27.8{ }^{\circ} \mathrm{C}$ with an average temperature of about $26.8{ }^{\circ} \mathrm{C}$. The lowest temperature occurred in August, while the highest temperature occurred in June every year. ${ }^{25}$

In 2016, the population of SSP reaches $8,160.901$ people with a sex ratio of 103.32 and population growth of 1.35 percent. $1,602,071$ people live in the city of Palembang, the capital of SSP, and another people stay in 16 districts/cities in SSP. The total workforce reached 4,178,794 inhabitants, 180,157 unemployment people, and the unemployment rate achieves 4.31 percent. The labour force participation rate of male population attained 85.13 percent and 57.67 percent for female. ${ }^{26}$ Based on $^{2}$ the highest level of education, 35.11 percent of the population of SSP only finish primary school education. The second largest proportion is people who graduated from high school (21.32 percent). The third most significant proportion of residents who graduated from junior high school (15.39 percent). While the population who felt education in universities/equivalent only 6.43 percent. In 2017, based on the poverty line (Rp370,060), the number of poor people in South Sumatra Province reaches 13.19 percent of the total population. This number

25 BPS Provinsi Sumatera Selatan, South Sumatera in Figure 2016 Palembang, Indonesia: BPS Provinsi Sumatera Selatan, 2017.

26 BPS Provinsi Sumatera Selatan, South Sumatera Data Series 2017, Palembang, Indonesia: BPS Provinsi Sumatera Selatan, 2017. decreased compared to the year 2016 which reached 13.39 percent. 65.54 percent of the poor population live in urban areas, and 34.46 percent are the rural inhabitant. ${ }^{27}$

The regional economy of SSP is dominated by three sectors: mining, manufacturing industry, and agriculture (including forestry and fishery). In 2016, these sectors have a significance contribute to Regional Gross Domestic Product (GRDP) as follows mining (19.89 percent), manufacturing industry (18.86), and agriculture (16.06 percent). In 2016, growth occurs in all business fields. However, the highest growth was in the electricity and gas procurement sector (17.32 percent), financial services and insurance (7.33 percent) and other services (6.50 percent). When viewed from the creation of sources of economic growth, the processing industry has the highest growth (1.15 percent), followed by construction ( 0.97 percent), and large/retail trade and motorcycle repair $(0.84$ percent). ${ }^{28}$

Currently, SSP consists of 17 districts, 232 sub-districts, 2,859 villages, and 377 kelurahan (the village in the urban area) (South Sumatera Central Agency on Statistics, 2017). It was led by Alex Nurdin (the Governor) and Ishak Mekki (the Vice of Governor) since 2013. SSP has 87,796 civil servants. Meanwhile, it has 73 people (60 male and 13 female) as the member of the SSP of the Regional House of Representatives (DPRD Provinsi Sumatera Selatan or Dewan Perwakilan Rakyat Daerah Provinsi Sumatera Selatan). The compo-sition of the SSP of the Regional

27 BPS Provinsi Sumatera Selatan, South Sumatera in Figure 2016.

28 BPS Provinsi Sumatera Selatan, South Sumatera Regional Statistics 2017, Palembang, Indonesia: BPS Provinsi Sumatera Selatan, 2017. 
House of Representative, based on the origin of political party, are come from the Indonesian Democratic Party of Struggle (Partai Demokrasi Indonesia Perjuangan or PDIP, 13 people), the Democrat Party (Partai Demokrat or PD, 10 people), the Great Indonesia Movement Party (Partai Gerakan Indonesia Raya or GERINDRA, 10 people), the Functional Group Party (Partai Golongan Karya or GOLKAR, 9 people), the Demo-cratic National Party (Partai Nasional Demokrat or NASDEM, 5), the Prosperous Justice Party (Partai Keadilan Sejahtera or PKS, 5 people), the United Development Party (Partai Persatuan Pembangunan or PPP, 2 persons), and the Crescent Star Party (Partai Bulan Bintang or PBB, 2 people). ${ }^{29}$

\section{The Legislation Process}

Normatively, according to the Regulation of the Ministry of Home Affairs Number 80 of 2015 on the Establishment of Local Law, legislation process has a set of standard operating procedure as follows: planning, initiation, negotiation, enactment, executive review, judicial review, implementation, and evaluation. This research, then, explaining this procedure with the concept of public policy formulation which consists of four stages: issue emergence, agenda setting, alternative selection, enactment, implementation, and evaluation. ${ }^{30}$ This research is ignoring the implementation and the evaluation phase because it is the outside of our research objectives.

29 BPS Provinsi Sumatera Selatan, South Sumatera in Figure 2016.

30 Thomas A. Birkland, Models of the Policy Process, in Encyclopedia of Public Administration and Public Policy, ed. Jack Rabin Florida, USA: Taylor \& Francis, 2005, pp188191.
In the first step, issue emergence, the forest fires in Indonesia, including South Sumatera, has been received attention from ASEAN since 1998. Because the forest fires are the regional problem, ASEAN agrees to release Regional Haze Action Plan (2001), Agreement on Transboundary Haze Pollution (2002), and create ASEAN Coordinating Centre for Transboundary Haze in Jakarta, Indonesia (Anonymous, 2016b). Under Jokowi - JK, the central government of Indonesia has given attention to this event due to its impact on economic development. As Jokowi's said do not let the widespread burning become difficult to overcome, and so I have said I no longer want to talk about the cause of the problem or what is the solution. Everyone knows what needs to be done. ${ }^{31}$ In 2015, the President of Jokowi release the President Instruction No. 11 of 2015 on Increasing Forest Fires Controlling to mitigate forest fires in Indonesia, particularly in Sumatera and Kalimantan Island.

In the agenda-setting phase, the executive (the Governor of SSP) and the province legislative (the SSP of Regional House of Representative) have authority to propose or initiate a new local regulation. In our cases, the initiator of The Provincial Regulation of South Sumatera No. 8 of 2016 on the Forest Fires Mitigation is the executive. Alex Nurdin, as the Governor of SSP, has created a special task force which consists of several civil servants to negotiate a local regulation draft on forest fires

31 Nazeer, Zubaidah. (2015) Indonesian President Joko Widodo Goes to Haze's Ground Zero. SE Asia News. Top Stories - The Straits Times. [Online] Available at: https://www.straitstimes.com/asia/se-asia/indonesian-president-jokowidodo-goes-to-hazes-ground-zero (retrieved: February 05, 2016). 
mitigation with a legislative committee. This step is a quick response of the Governor of SSP to the Presidential Instruction No. 11 of 2015 on Increasing Forest Fires Controlling. For Alex Nurdin, the creation of local regulation on forest fires mitigation is a part of the Movement of Forest Fires Controlling in South Sumatera. This movement, said Alex Nurdin, was inspired by Talang Tuo inscription which showing the spirits, aspirations, the visions, and practice of environmental conservation as the cultural heritage of South Sumatera's people, notably the Kingdom of Sriwijaya. ${ }^{32}$

For the SSP of the Regional House of Representatives, forest fires are crucial problems in South Sumatera. The South Sumatra Province of Regional House of Representative has been sent a message to the executive to propose a local regulation on forest fires mitigation (AN, member of the SSP of the Regional House of Representatives from the Golkar Party). ${ }^{33}$ At the same time, several element of civil society in SSP such as the Coalition of South Sumatera People (Koalisi Rakyat Sumatera Selatan), the Palembang Branch of Indonesian Islamic Student Movement (Pergerakan Mahasiswa Islam Indonesia Kota Palembang), the Palembang Resources Watch (Sumber Daya Watch Palembang), and the Palembang Branch of the Women's

32 Rahmadi, Rahmad. (2016) Prasasti Talang Tuwo, Amanat Sakral Sriwijaya Mengenai Tata Lingkungan Sejak Dulu. Mongabay Indonesia. [Online] Available at: http://www.mongabay.co.id/2016/03/14/prasasti-talang-tuwo-amanatsakral-sriwijaya-mengenai-tata-lingkungan-sejakdulu/ (retrieved: April 20, 2017).

33 Wahyudi, Aan. (2015) Sumsel Harus Miliki Perda Kebakaran Hutan Dan Lahan - Rmolsumsel.Com. Rakyat Merdeka Online. [Online] Available at: http://www.rmolsumsel.com/read/2015/08/04/339 23/Sumsel-Harus-Miliki-Perda-Kebakaran-Hutandan-Lahan- (retrieved: August 07, 2017). of Hisbut Tahrir Indonesia (Muslimah Hisbut Tahrir Indonesia Kota Palembang), is also give attention and articulate their aspirations through the SSP of the Regional House of Representatives. ${ }^{34}$ The voice of civil society does not see the forest fires as the basis to create a new local regulation on forest fires. Instead, they articulate several ideas who represent their subjective view on forest fires such as ecological disaster and law enforcement (Koalisi Rakyat Sumatera Selatan), the victim of forest fires and the revocation of forest licence (Pergerakan Mahasiswa Islam Indonesia Kota Palembang, Sumber Daya Watch Palembang, and Muslimah Hisbut Tahrir Indonesia Kota Palembang). This research does not find the element of civil society who propose a new local regulation on forest fires mitigation to remedy this problem. It is mean that creating a new local regulation on forest fires mitigation is not a bottom-up agenda, but a top-down agenda.

As the initiator of a new local regulation on forest fires mitigation, the executive task force should prepare an academic manuscript. The Government of South Sumatra Province make several events to finalize academic manuscript on forest fires mitigation such as public discussion, technical meeting, comparative study, and public assessment (TK, a senior civil servant in the Agency of Forestry, South Sumatera Province, interview, 17 May 2017). However, several civil society organizations in

34 The Secretariat of South Sumatera Province of the Regional House of Representatives, The Government Institution's Performance Accountability Report of the Secretariat of South Sumatera Province of the Regional House of Representative, Palembang, Indonesia: The Secretariat of South Sumatera Province of the Regional House of Representatives, 2015. 
Palembang City stated that this local regulation is created suddenly without participation from environmental NGO activist in South Sumatera. ${ }^{35}$ The Governor of SSP submitted the final version of the academic manuscript to the Regional Legislation Program of the South Sumatera Province of The Regional House of Representative.

The Chief of the South Sumatera Province of the Regional House of Representative creates a special committee to discuss the academic manuscript with the executive's task force. The member of the special committee is recruited from all political party in the South Sumatera Province of the Regional House of Representative. The Chief of the South Sumatera Province of the Regional House of Representative is only given one month for the special committee and the executive task force to discuss and finalize legal draft on forest fires mitigation. The Chief of the South Sumatera Province of the Regional House of Representative will approve or reject the legal draft on forest fires mitigation in SSP based the recommendation of the special committee. On the other words, the special committee should be applying a critical thinking towards the legal draft proposed by the executive task force.

The essence of the alternative selection is how to accept, reject, or revise the argumentation of the executive's ideas behind the legal draft using multiple approaches (i.e., legal, political, economic,

35 Wijaya, Taufik. (2016) Sumatera Selatan Punya Perda Karhutlah. Tahukah Pegiat Lingkungan Hidup?. Mongabay Indonesia. [Online] Available at: http://www.mongabay.co.id/2016/07/20/sumat era-selatan-punya-perda-karhutlah-tahukahpegiat-lingkungan-hidup/ (retrieved: April 20, 2017). sociological, and ecological approach). It is true that each party has a different opinion on the forest fire in SSP. However, this research does not find each political party build opposition attitudes towards the legal draft proposed by the executive's task force. Based on secondary data analysis, this research finds that the role of the special committee similar to a professional editor or a professional proof-reader. They focused on spelling and grammatical error, law synchronization, but ignoring 'no burning policy' which is rejected by NGO activist in South Sumatera Province. On 31 March 2016, The Chief of the SSP of the Regional House Representative enactment the final draft of forest fires mitigation in the Fifth Plenary Session of the SSP of the Regional House Representative.

\section{Actor Policy Belief}

ACF theorist argues that each policy actor has policy belief which consists of three layers: deep core belief (DCB), policy core belief (PCB), and secondary policy belief (SPB). This research will focus on secondary policy belief because of it very dynamics than DCB and PCB. We apply an 'environmental narrative' to construct SCB's actors. Shortly, an environmental narrative is policy actor perception on forest fires which consists of three elements: the cause, the solution, and the impact. We use NVIVO 11 software to coding data from the interview, social media, newspaper, website, and the official publication of government, plantation corporation, and non-governmental organization. This process provides the SCB's narrative that represents the logic of causality (cause - impact — solution) all actor on forest fires implicitly (see Table 1).

Table 1: The Actor's SCB Narrative

Policy actor Secondary policy belief narrative 


\begin{tabular}{|c|c|}
\hline $\begin{array}{l}\text { The Government } \\
\text { of } \\
\text { Sumatera } \\
\text { Province }\end{array}$ & $\begin{array}{l}\text { The cause of forest fires is } \\
\text { natural and human factors. The } \\
\text { forest fires generate ecological, } \\
\text { social and economic impacts that } \\
\text { must be prevented and mitigated } \\
\text { through weather monitoring, } \\
\text { education and community partic- } \\
\text { ipation, audits on forest fire } \\
\text { controls audits in plantation con- } \\
\text { cessions, no burning policy, rein- } \\
\text { forcement an integrated team on } \\
\text { combating forest fires, water } \\
\text { bombing, weather modification, } \\
\text { land rehabilitation, and law } \\
\text { enforcement. }\end{array}$ \\
\hline $\begin{array}{l}\text { The South } \\
\text { Sumatera } \\
\text { Province of the } \\
\text { Regional House } \\
\text { of } \\
\text { Representative }\end{array}$ & $\begin{array}{l}\text { The cause of forest fires is } \\
\text { natural factors and human } \\
\text { factors. It has ecological damage, } \\
\text { economic losses and disrupt } \\
\text { human life activities that must be } \\
\text { prevented and mitigated through } \\
\text { law enforcement, no burning } \\
\text { policy, improving investment } \\
\text { regulations in the plantation } \\
\text { sector, infrastructure develop- } \\
\text { ment, fires technology pro- } \\
\text { curement, environmental rehabil- } \\
\text { itation, community development, } \\
\text { and improving disaster manage- } \\
\text { ment. }\end{array}$ \\
\hline Scientist & $\begin{array}{l}\text { The cause of forest fires is } \\
\text { natural, government, and com- } \\
\text { munity factors. It has ecological } \\
\text { damage, economic losses, and } \\
\text { disrupt human life activities that } \\
\text { must be prevented and mitigate } \\
\text { through peatland restoration, } \\
\text { community participation, inte- } \\
\text { grated prevention and mitigation, } \\
\text { and managing local wisdom. }\end{array}$ \\
\hline
\end{tabular}

\begin{tabular}{|c|c|}
\hline $\begin{array}{l}\text { Environmental } \\
\mathrm{NGO}\end{array}$ & $\begin{array}{l}\text { The cause of forest fires is } \\
\text { natural and community factors. It } \\
\text { creates ecological damage, } \\
\text { economic losses and disrupts } \\
\text { human life activities. The forest } \\
\text { fires should be prevented and } \\
\text { mitigated through law enforce- } \\
\text { ment, improving investment } \\
\text { regulations in the plantation } \\
\text { sector, infrastructure develop- } \\
\text { ment, fires equipment pro- } \\
\text { curement, environmental reha- } \\
\text { bilitation, community devel- } \\
\text { opment, participation and } \\
\text { education, financial support, } \\
\text { equitable land distribution, } \\
\text { integration of sustainable de- } \\
\text { velopment principles into local } \\
\text { development, peatland resto- } \\
\text { ration, and respecting local wis- } \\
\text { dom. }\end{array}$ \\
\hline $\begin{array}{l}\text { Plantation } \\
\text { corporation }\end{array}$ & $\begin{array}{l}\text { The cause of forest fires is } \\
\text { community factors, especially } \\
\text { slush-and-burning agriculture. It } \\
\text { threatens the economy, human } \\
\text { lives, reduces the value and } \\
\text { productivity of company } \\
\text { assets, and creates transboundary } \\
\text { haze, degrades soil nutrition, } \\
\text { affects water quality, enhances } \\
\text { the risk of soil erosion, and } \\
\text { change sustainable management } \\
\text { of plantations. It should be } \\
\text { resolved through no burning } \\
\text { policy, detect, prevent and handle } \\
\text { fire incidents using advanced } \\
\text { technology and collaborative } \\
\text { approach, and allocate budget } \\
\text { regularly to financing fires } \\
\text { controlling program. }\end{array}$ \\
\hline
\end{tabular}

Source: analysed from the primary source

Table 1 shows the similarities and differences of actors' perceptions of the causes, impacts, and solutions of forest fires explicitly. At the causes dimension, all policy actor agrees that the natural and the human factors contribute to the forest fires. All policy actor believes that the forest fires have significant effects on human beings 
(i.e., economy, politics, and social) and ecology. However, all policy actors have a different opinion on 'no burning policy' in The Provincial Regulation of South Sumatera No. 8 of 2016 on the Forest Fires Mitigation. As shown in Table 1, three actors (The Government of South Sumatera Province, The South Sumatera Province of the Regional House of Representative, and plantation corporation) agree to prohibit this practice at small farmer and corporation level. Other actors, environmental NGO, and scientist agreed to forbid this practice at corporation level only but authorized it at small farmer level. Based on this finding, this research argues that the SCB's policy actor during the formulation of The Provincial Regulation of South Sumatera No. 8 of 2016 on the Forest Fires Mitigation follows two patterns: partially different or the same overall. This finding becomes our empirical basis to analyse the formation of the advocacy coalition during the formulation of The Provincial Regulation of South Sumatera No. 8 of 2016 on the Forest Fires Mitigation.

\section{The Advocacy Coalition}

For ACF theorist, advocacy coalition is a set of policy participant who makes cooperation based their similarities on policy belief to influence the policymaking process. In our case, the basis for this similarity is policy participant attitudes towards 'no burning policy' and 'slash-and-burn' agriculture. Based on the previous findings, this research identifies two advocacy coalition during the formulation of The Provincial Regulation of South Sumatera No. 8 of 2016 on the Forest Fires Mitigation. First, 'no burning policy' coalition which possesses three members (The Government of South Sumatera Province, The South Sumatera Province of the Regional House of Representative, and plantation corporation). Second, 'local wisdom' coalition which owns two members (environmental NGO and scientist).

ACF predicts that each advocacy coalition will influence the policymaking process. Each member of the advocacy coalition will share resources and formulate the best strategy to articulate their policy preferences. When there is a conflict between two or more advocacy coalition, 'the policy broker' will mediate to resolve this conflict based on win-win solutions. Unfortunately, our finding does not support this prediction overall. First, although the plantation corporation has similar SCB with the executive and the legislative, they still cannot fully participate in legislation process due to closed-door of participation window. Second, 'no burning policy' coalition make legis-lation process as a restricted area and do not permit 'local wisdom' coalition to fully participate and articulate their policy preferences. Third, this research does not find policy participants which playing the role as the 'policy broker'. This research predict that the central government and the judiciary institution will play this role through 'the executive review' and 'the judicial review' mechanism. However, this research does not find this mechanism resolve 'no burning policy' issue between 'local wisdom' coalition and 'no burning policy' coalition. However, this research agrees that there are resources sharing (i.e., information) among advocacy coalition member. Because they have a limited role in the legislation process, 'local wisdom' coalition choose to influence the policy making process through the media (newspaper, magazine, broadcasting, and social media). 


\section{CONCLUSION}

From what had been explained above, there are some conclusions drawn up here as follow:

1. The finding supports the strength of ACF to understanding cooperation between policy participants using 'policy belief' and 'advocacy coalition.'

2. However, not all ACF predictions are adequate to explain the process of local legislation. Firstly, ACF was built based on Western democracy in which 'participation window' is always opened, whereas 'participation window' in Indonesia at the local level could be opened or closed. Secondly, there is another consideration the role of policy belief as the basis of cooperation among the policy participant. The prominent ACF theorist, argues that PCB and not $\mathrm{SCB}$ is the glue of policy participant to create the 'advocacy coalition.' It is argued that based on the empirical finding, that SCB could be the foundation of 'advocacy coalition' formation. This research shows that it is possible to analyse PCBs and SCBs separately even though they are part of the same concept (the policy belief).

3. The practical implication of the research is that the elite of and the Government Province of South Sumatra, the Regional People's Representative Assembly (Dewan Perwakilan Rakyat Daerah) as well should promote citizen participation in formulating local regulations.

4. Due to the rapid development of the information technology, the Regional People's Representative Assembly should make 'participation window' always opened all the time.
5. Although the Provincial Government of South Sumatra perceipts the annual forest fires is not serious public problem, the local government should change their mindset of bureaucratic governance to collaborative governance.

6. The Government of South Sumatera should amend the local regulations on the forest fires mitigation, particularly on the 'no burning policy'. This is because the regulation is not aligned with the local wisdom practiced in South Sumatera Province and the narrative character of the local decision-making processes.

\section{Acknowledgment}

Thank you for all policy participants who already in sharing information on the forest fires legislation. There is no conflict of interest during the research process.

\section{REFERENCES}

\section{Books}

Agranoff, Robert, and Michael McGuire. 2003. Collaborative Public Management: New Strategies for Local Governments. Washington D.C., USA: Georgetown University Press.

Birkland, Thomas A (ed). 2005. Models of the Policy Process in Encyclopaedia of Public Administration and Public Policy. Florida, USA: Taylor \& Francis.

BPS Provinsi Sumatera Selatan. 2017. South Sumatera Data Series 2017. Palembang, Indonesia: BPS Provinsi Sumatera Selatan.

BPS Provinsi Sumatera Selatan. 2017. South Sumatera in Figure 2016. Palembang, Indonesia: BPS Provinsi Sumatera Selatan.

BPS Provinsi Sumatera Selatan. 2017. South Sumatera Regional Statistics 2017. Palembang, Indonesia: BPS Provinsi Sumatera Selatan.

Cooper, Karyn, and Robert E White. 2012. 
Qualitative Research in the Post-Modern Era: Contexts of Qualitative Research. Dordrecht, The Netherlands: Springer Science + Business Media B.V.

Hill, Michael, and Peter Hupe. 2002. Implementing Public Policy. London, UK: SAGE Publication Ltd.

Jenkins-Smith, H C, D Nohrstedt, C M Weible, and Paul A. Sabatier (ed). 2014. The Advocacy Coalition Framework: Foundation, Evolution, and Ongoing Research in Theories of the Policy Process., edited by Paul A. Sabatier and Christopher M. Weible, Third. Colorado, U.S.A: Westview Press.

McBeth, Mark, Michael Jones, and Elizabeth Shanahan. 2014. The Narrative Policy Framework in Theories of the Policy Process, edited by Paul A. Sabatier and Christopher M Weible, Third. Philadelphia, USA: Westview Press.

Miles, Matthew B, A Michael Huberman, and Jhonny Saldana. 2014. Qualitative Data Analysis: A Method Sourcebooks. London, UK: SAGE Publication.

Sabatier, Paul A, and C M Weible. 2007. The Advocacy Coalition Framework: Innovations and Clarifications. Edited by Paul A. Sabatier. Theories of the Policy Process. Colorado, U.S.A: Westview Press.

Smith, Kevin B., and Christopher W. Larimer. 2009. The Public Policy Theory Primer. Colorado, U.S.A: Westview Press.

The Secretariat of South Sumatera Province of the Regional House of Representatives. 2015. The Government Institution's Performance Accountability Report of the Secretariat of South Sumatera Province of the Regional House of Representative. Palembang, Indonesia: The Secretariat of South Sumatera Province of the Regional House of Representatives.

\section{Journals}

Ardhanariswari, Riris, Sofa Marwah, and Tedi Sudrajat. 2008. "Keterlibatan Perempuan Dalam Penyusunan Produk
Hukum Di Kabupaten Banyumas." Jurnal Dinamika Hukum. 8.

Black, Julia. 2002. "Regulatory Conversations." Journal of Law and Society. 29 (1).

Conybeare, John A C. 1982. "Politics and Regulation: The Public Choice Approach." Australian Journal of Public Administration 41 (1).

Crawford, Sue E. S., and Elinor Ostrom. 1995. "A Grammar of Institutions." American Political Science Review. 89 (3).

Dowding, Keith. 1995. "Model or Metaphor? A Critical Review of the Policy Network Approach." Political Studies. 43 (1).

McKenzie, Richard B., and Hugh $\mathrm{H}$ Macaulay. 1980. "A Bureaucratic Theory of Regulation.” Public Choice. 35 (3).

Mitnick, Barry M. 1982. "Regulation and the Theory of Agency." Review of Policy Re-search. 1 (3).

Muhiddin, Amir. "Partisipasi Masyarakat Dalam Pembuatan Peraturan Daerah (Perda)." OTORITAS: Jurnal Ilmu Pemerintahan. 3 (1).

Peltzman, Sam. 1976. "Toward a More General Theory of Regulation." The Journal of Law and Economics. 19 (2).

Rasyid, Ruslan Abdul. 2013. "Politik Hukum Pembentukan Peraturan Daerah Nomor 5 Tahun 2006 Tentang Investasi Infrastruktur Jalan Dan Landing Site Eks Jalan Pertamina Oleh Pemerintah Kabupaten Barito Timur." Arena Hukum. 6 (3).

Sabatier, Paul A. 1998. "The Advocacy Coalition Framework: Revisions and Relevance for Europe." Journal of European Public Policy. 5 (1).

Sabatier, Paul A. 1986. "Top-Down and Bottom-Up Approaches to Implementation Research: A Critical Analysis and Suggested Synthesis." Journal of Public Policy. 6 (1).

Saleh, Ahmad. 2015. "Peran Serta 
Masyarakat Di DPRD Dalam Pembentukan Peraturan Daerah." Fiat Justisia. 7 (2).

Shleifer, Andrei. 2005. "Understanding Regulation." European Financial Management. 11 (4).

Sri Nurhidayati. 2013. "Proses Perumusan Kebijakan Pertambangan Di Kabupaten Sumbawa." JKAP (Jurnal Kebijakan Dan Administrasi Publik). 17 (1).

Tollison, Robert D. 1988. "Public Choice and Legislation." Virginia Law Review. 74 (2).

Stanbury, W.T., and George Lermer. 1983. "Regulation and the Redistribution of Income and Wealth." Canadian Public Administration/Administration Publique Du Canada. 26 (3).

Stigler, George J, and Claire Friedland. 1962. "What Can Regulators Regulate? The Case of Electricity." The Journal of Law and Ec-onomics. 5.

Sucahyo, Imam. 2017. "Partisipasi Stakeholders Islam Dalam Upaya Mereformasi Peraturan Daerah Tentang Usaha Tempat Hibutan di Kota Probolinggo." Publisia. 2 (2).

Yusdiyanto. 2012. "Partisipasi Masyarakat Dalam Pembentukan Program Legislasi Daerah." Fiat Justisia. 5 (2).

\section{World Wide Web}

Ihsanuddin, Ihsanuddin. "Daftar 3.143 Perda Yang Dibatalkan Sudah Bisa Diunduh Di Situs Kemendagri." www.kompas.com, 2016.
Available at: https://nasional.kompas.com/read/2016/06/21/15200401/daftar.3 .143.perda.yang.dibatalkan.sudah.bisa.diund uh.di.situs.kemendagri. [retrieved: June 09, 2017]

Nazeer, Zubaidah. "Indonesian President Joko Widodo Goes to Haze's Ground Zero, SE Asia News \&amp; Top Stories - The Straits Times." www.straitstimes.com, 2015. Available at: https://www.straitstimes.com/a sia/se-asia/indonesian-president-jokowidodo-goes-to-hazes-ground-zero. [retrieved: February 05, 2016]

Rahmad, Rahmadi. "Prasasti Talang Tuwo, Amanat Sakral Sriwijaya Mengenai Tata Lingkungan Sejak Dulu." Mongabay Indonesia, 2016. Available at: http://www.mongabay.co.id/2016/03/14/pras asti-talang-tuwo-amanat-sakral-sriwijayamengenai-tata-lingkungan-sejak-dulu/. [retrieved: April 20, 2017]

Wahyudi, Aan. "Sumsel Harus Miliki Perda Kebakaran Hutan Dan Lahan Rmolsumsel.Com." Rakyat Merdeka Online, 2015. Available at: http://www.rmolsumsel. com/read/2015/08/04/33923/Sumsel-HarusMiliki-Perda-Kebakaran-Hutan-dan-Lahan- . [retrieved: August 07, 2017]

Wijaya, Taufik. "Sumatera Selatan Punya Perda Karhutlah. Tahukah Pegiat Lingkungan Hidup?" Mongabay Indonesia. July 2016. Available at: http://www.mongab ay.co.id/2016/07/20/sumatera-selatanpunya-perda-karhutlah-tahukah-pegiatlingkungan-hidup/ [retrieved: April 20, 2017]. 